Bulletin of the Transilvania University of Braşov

Series IV: Philology and Cultural Studies • Vol. 13(62) Special Issue

https://doi.org/10.31926/but.pcs.2020.62.13.3.12

\title{
Language policies and multilingualism in modern Tunisia
}

\author{
Ibtissem SMARI ${ }^{1}$, Ildikó HORTOBÁGYI²
}

In a multicultural and multilingual world, people negotiate their identities along contextual lines. Online mediated information about countries and cultures build bridges at the individual level and create a sense of "global citizenship" (Hortobagyi 2015; 2017). Languages policies and linguistic landscapes facilitate the exploration of the multilingual texture of a country, thus research in imminently multicultural environments fosters a better understanding of multiple linguistic identities. Situated at the intersection of social and language sciences, drawing on relevant literature and using a comparative approach, the presentation highlights Tunisia's long history of linguistic and political confrontation since its independence from France (Riguet 1984) and focuses on the educational reforms that have been undertaken, particularly on the various policies and guidelines pertaining to modifying the language policy of the country. Since the 1970s, a significant process of Arabization has been underway, alongside the strengthening of bilingual education, which was launched as early as 1956. Considering that English started to be taught in Tunisian schools shortly after the independence (Battenburg 1997), Tunisian education has always been trilingual with English as the most common foreign language added to Arabic and French. The first years of the 21st century were marked by the introduction of additional foreign languages in secondary education, such as Russian, Spanish, Italian, Chinese, German, and Turkish among others. All these policies have allowed Tunisia to access modernity (Messadi 1967 cited in Belazi 1991, 53). Currently, Tunisian Arabic and Berber are languages that have not yet been added to the political agenda. Nevertheless, the return to the standardization of Arabic through teaching, the noticeable decline of the use of French, and the emergence of English as a new alternative, indicate linguistic policies in which multilingualism is becoming the new norm, with manifest representations both at the societal level and in the new media communication.

Key-words: education, multilingualism, language policy, identity

\footnotetext{
1 University of Pannonia, Veszprém, Hungary, smariibtissem.si@gmail.com

2 University of Pannonia, Veszprém, Hungary, ildiko@almos.uni-pannon.hu
} 


\section{Introduction}

In a globalized world, where increased international mobility has altered the cultural fabric of societies, a multidisciplinary approach to understanding the dynamics of communication in general, and multicultural communication, in particular, has proved indispensable. The different branches of applied linguistics (sociolinguistics, psycholinguistics, language policy, just to mention the most relevant ones to our discussion), coupled with new research areas in metrolingualism, media linguistics, translanguaging, or computer-mediated discourse analysis prove to be a solid ground for investigating the impact the presence of international students in higher education can have on developing a conscious awareness of the multicultural and multilingual competencies needed for mutual comprehension. Echoing Coupland (2016), who argues that:

"As language users, we are all theorists, although the discipline of sociolinguistics has particular responsibilities in fostering, through its theory, awareness of what happens at the interface between language and society, and in reviewing what we know and what we have not yet adequately explained." $(2016,1)$

We need to investigate practices of using and interpreting language in society, as meanings are deconstructed, reconstructed, and negotiated according to the standing of the interlocutor's cultural norms and linguistic environment. Therefore, to anchor our paper against this complex backdrop, a brief detour into tackling the concept of identity must be considered. To recognize and decode a person's enacted multicultural identities, we need to understand how the language identities a person displays in different environments have been shaped, among other salient factors, by the language policies of their countries of origin.

In most formerly colonized countries, linguistic diversity has been seen as the cause of maintaining the colonial language as the official language, either alone or together with one of the national languages. In the wake of their independence, the Maghreb states declared Arabic as their national and official language, officially excluding French and above all, the mother tongues: dialectal Arabic and Berber (for Algeria and Morocco).

Today, almost half a century after independence, the record of the language policy adopted in the field of education by the three Maghreb countries can be summarized as follows. Tunisia, the most linguistically homogeneous country, is the most francophone one. Algeria, where the duration of the colonization was the longest, is the most Arabized. Morocco, where the French presence has been the 
shortest, is situated halfway from both extremes. This means that despite the commonality of Arabic as the official language, states have followed different language policies. As described in Smari and Navracsics (2019), several generations of Tunisians have had various encounters with the language use in social and workplace, in the instructive framework, in the legislature, and in the media. In this context, Daoud (2001) reported that language policy and planning in Tunisia was, at once, instrumental in shaping such experiences and attitudes and subject to their influences.

This research aims to reflect on the postcolonial language policy adopted by Tunisia since its independence, focusing on the field of education, and to examine it briefly in relation to language practices in social life by exploring these practices in the new media communication. Our purpose is to try to show how this language policy is at the centre of a double paradox: on the one hand, it is officially claimed to be an Arabic monolingualism in a real situation of multilingualism. The languages in question thus have functions that contradict their official status. They are in a relationship of conflict; as in all situations of contact, one language is facing the other in a relationship of domination and not of simple coexistence. The dominant language, and thus the language of social success, remains French. Nearly half a century after the independence, the language policy of Arabization as it was conceived, contrary to its very principle of rehabilitating Arabic, has instead reinforced French, which can neither be erased nor given a clear status.

On the other hand, the language policy projects ideological functions on the two languages, such as the colonial language and the national language, authenticity vs. modernity, the first associated with Arabic, the second with French, opposing the languages to each other. It is based on two separate languages, both of which are urgently required for the affirmation of Tunisia's independence and its desire to be an actor in its history. To erase the cultural traces of colonization, Arab authenticity and identity with reference to the past will be achieved through classical Arabic, and the need for modernity and progress will be achieved through French. This is the second and the most profound paradox which seems to exclude the people through these two languages and intends to accomplish the project of a national, autonomous, authentic and modern society through two separate languages, neither of which being authentic. Modernity, instead of being conceived as a process internal to society and expressed in its language, is going to be subordinated to the language of the former "master" who precisely justified colonialism in the name of progress, and imposed "his" language for that purpose.

Thus, the projection of "authenticity" on the Arabic language and "modernity" on the French language forms the backdrop of language policy, influencing social discourse and user representations of these languages. To a 
certain extent, it is questionable whether there has been a break with colonial ideology and the perceptions it has conveyed about the language of the colonizer and the language of the colonized. This paradoxical duality has undoubtedly had a visible impact equally on identity development. Nowadays the cultural exchanges have accelerated to the point where societies are interconnected in all walks of life; therefore, their members need to develop solid language abilities and cultural knowledge. The ability to study abroad as well as to work in a multicultural and multilingual background is key to business and private success. Therefore, we need to understand the history of the people coming from a multilingual background.

\section{Language in the history of colonization and decolonization in the Maghreb}

When comparing the duration of the colonization of the three North African countries, we can notice a difference that distinguishes Algeria from Tunisia and Morocco. France's colonial linguistic domination affected Algeria more than the other two countries, but overall, we could note that the difference is in degree, not in nature.

In Algeria, French was to marginalize and then eliminate the teaching of Arabic. The Arabic language and its referent, Islam, were perceived as a source of resistance against the project of assimilation. French was imposed and usurped, as Lacheraf (1965) put it, its status as an official language. Arabic was declared a foreign language in 1938. In Tunisia and Morocco, the teaching of Arabic was maintained, but in all three countries, French was the official language of education, administration, and sectors of economic life. Much has been written on the subject of the linguistic and cultural hegemony of colonization, which led to the devaluation of the Arab language and culture, and invested French with a dual function of superiority.

French was at once the only official language and therefore had the status of a dominant language, meanwhile having a symbolic function of social and cultural distinction, through the social stratification linked to its employment and through schooling that affected an elite. In 1930, the school enrolment rate in relation to the school-age population was 6.6 per cent in Tunisia, 5.90 per cent in Algeria, and 1 per cent in Morocco (Sraïeb 1974). Tunisia made some progress in the final years of colonization to reach the percentage of 11 per cent of pupils enrolled at all levels. Here, the idea that the French wanted to make French the mother tongue of the Maghreb must be revised. Education was perceived as a danger and was reserved for the elite. This is evidenced by the illiteracy rate estimated to be between $80 \%$ and $90 \%$ at the time of the independence. There is, thus, a seduction 
both for those who learn it and for those who are deprived of it. Fascination and its flipside, the rejection of French, are coupled with the rejection of oneself (cf. the so-called French-speaking Maghreb literature). Cultural and linguistic alienation has been perceived as the product of this linguistic domination and the devaluation of the culture of the colonized and their identity.

This calls us to reflect on the distinction that is often made between British and French colonialism in relation to linguistic matters. The English allowed the learning of mother tongues while the French only recognized the French language. This can be confirmed in the following passage quoted by Pierre Alexandre (1967) in "Langues et langage en Afrique noire" (Languages and speech in Black Africa):

In educational matters, the linguistic policy of the French colonisation is very easy to define: it is the policy of King Francis 1 of France, of Cardinal Richelieu, of Robespierre and of Jules Ferry. Only one language is taught in schools, allowed in the legal courts, used in administration: the French language, as defined by the French Academy and the decrees of public instructions. All the other languages are nothing more than folklore, ballet dancing skirt, a Mayday call, obscurantism and ferments of the disintegration of the Republic. (Alexandre 1967, 71) [Authors' translation]

It should be noted that this colonial language policy was largely influenced by the policy practiced in metropolitan France, which was aimed at eradicating regional languages through schools. In the Maghreb, it is the classical Arabic language, which is also highly standardized and which represents the strong symbol of identity that has been considered a danger. Dialectal Arabic, in the philosophy of language inherited from the history of the imposition of French in France against Latin and patois, was not considered a rival to French. This explains why it was taught in French schools in Tunisia until recently. Paradoxically, the republican school taught patois in the colonies. As for the Berber, already dominated by Arabic, it was perceived as an ally of French and potentially of the colonial project itself. This was a strategy and not a real consideration for the oral mother tongues of the colonized. We also have to admit that at any time in history, within each society there is a dominant culture, which is not monolithic, and the numerous cocultures and specialized cultures have always maintained their linguistic legacy. To oppose this colonialism based on French as a means of domination, liberation movements made Arabic the symbol of the identity of the colonized and the basis of the call for independence. As noted in A. Bounfour (1994, 18): "The colonial state, by crystallizing the debate of frankness against Arabity, has produced its protest based on this same paradigm but reversed." 
Once the colonizer is driven out and independence is achieved, the three Maghreb States inscribe the Arabic language, a symbol of the recovered identity, as the national language in the text of their respective constitutions and Islam as the state religion. The Tunisian Constitution stipulates in article 1 and in the same sentence that Tunisia is a republic, its language is Arabic and its religion is Islam. Grandguillaume (1983) (as cited in Jerad, 2004, https://books.openedition. org/irmc/1495?lang=en, accessed in September 2020) stated that "To oppose a language introduced in the name of its prestige, only classical Arabic can rival it". To erase the trauma of deculturation and rehabilitate an identity scorned by colonialism, the Arabization policy proclaimed at the time of independence of the three countries was to give priority to education, administration, and the environment.

\section{Tunisia's linguistic panorama}

Daoud $(2011,9)$ describes Tunisia's linguistic history as "being marked by multiplicity, diversity, and accommodation rather than having one language". The indigenous people of Tunisia spoke a language referred to as Lybic, which is the oldest language spoken there. Bilingualism is not new in the linguistic profile of the country. In fact, it began with the arrival of the Phoenicians from Tyre (Lebanon), who founded the Carthaginian Empire (814-146 BCE). Since then, Lybic/ Punic bilingualism developed over seven centuries according to Daoud $(2011,9)$. The coming of the Romans to the region opened the way to multilingualism with Berber, Punic and Latin being the main languages spoken at that time. During the early seventh century, which was marked by the spread of Islam in North Africa, the linguistic situation changed dramatically. Islam fetched Arabic, which took several years to become the official language of Tunisia. As a result of the conversion of a great number of Berbers (the indigenous people) to Islam, the Berber language lost its position considerably, giving way to Arabic to become the official language. In fact, Berber is now spoken by less than $1 \%$ of the population and is considered 'a dying language' (Daoud 2011, 10). With Arabic becoming the official language, the linguistic development did not come to an end. Since then, the area witnessed multiple invasions from different European authorities. As a result, it allowed for contact with several modern European languages such as Arab/ Moor Berbers (from Spain), Spaniards (with the arrival of Christians), and Muslims (Turks). The 19th century witnessed other linguistic changes with the coming of Italians and French, who indeed settled in Tunisia joining the competition. After France colonized Tunisia in 1881, the French language became 
more than the language of the colonizer, but a means of communication for a great number of people. French was widely used after the independence in different domains to the extent it gained the status of a 'second language' as stated by Daoud $(2011,11)$.

\section{Language policy and planning in education}

From a historical and a political point of view, Tunisia is an ex-French colony and this makes it essentially a francophone country. As early as it got its independence in 1956, a process of bilingual education was launched. It was based on early literacy in Arabic followed by the early introduction of French. In secondary school, education has always been trilingual with English as the most common foreign language added to the two languages already taught, Arabic and French. The first years of the 21st century were marked by the introduction of other foreign languages to the secondary school like Russian, Spanish, Italian, Chinese, German, Turkish, etc. This environment has yielded multiple linguistic identities, which are visible in the translanguaging and code-switching processes present in contemporary real-time and virtual communication. A student from Tunisia, for example, can choose to display his/her linguistic identities in different communication strings on different digital platforms.

\subsection{History of educational reforms}

In Tunisia, since the independence of 1956, the education of young people has received the greatest attention from political leaders. The language choices concerning curricula have also been the subject of many strategic shifts. We can thus identify, broadly speaking, three major periods, which in turn saw the promotion of French or its disgrace in the Tunisian education system.

\subsubsection{Before the protectorate (before 1881)}

Before France established the protectorate in Tunisia, many schools that promoted a bilingual and a bicultural system had already been established. Ahmed Bey created the Polytechnic School of Bardo, which became the Military School and charged Colonel Calligari with the organization of the new teachings, namely the introduction of foreign languages including Italian and French, as these two languages have been considered as the languages of modernism (Sraieb 2000, 213). The officers, who had graduated from the Bardo Military School, their professors as well as some 
members of the Zitouna ${ }^{3}$ initiated these first reforms. Kheredine, appointed Prime Minister in 1873, concretized these new resolutions by creating in 1875 the Sadiki college of Tunis by order of Mohammed al Sodok, the Bey ${ }^{4}$ of Tunis (Degorge 2002). The College aimed to provide education in European languages and sciences. Tullon (2009) points out that this bilingual model is considered important for Tunisia, in particular for three reasons of modernisation such as (1) Opening up to Europe; (2) scientific catch-up; and (3) technological catch-up (Tullon 2009, 41).

Thus, by training future executives capable of managing the country thanks to a diversified education ranging from sciences to languages (French, Turkish, Italian), the country could claim to achieve modernity and progress. Upon their arrival in Tunisia, the French found bilingual executives who acted as a link between the colonial authorities and the population.

It is worth mentioning that there were also schools for the Italian and the French residents living in Tunisia (Degorge 2002). In 1843, the Italians were the first to open a school exclusively for Italians. Two years later, the French opened a "national" school abroad. Thus, the presence of French in Tunisia seems to be antecedent of the protectorate, but it should be stressed that it remained reserved for residents of French origin. This changed with the protectorate and the Tunisian population was faced with changes in its daily life, including the experience of a modernization of the education system (Tullon 2009; Degorge 2002; World Bank 2008) led by the French, as described below.

\subsubsection{During the protectorate (1881-1955)}

The Treaty of Bardo signed on May 12, 1881, placed Tunisia under the protection of France. Although the Bey officially remained the legitimate sovereign, economic, political, and administrative powers fell into the hands of the colonizer. The process of colonization intensified as the number of French officials increased. France thus chose to implement a "policy of association".

A policy of association, which - preserving the economic and political interests of the colonizer, and supposing that there exists a more advanced society that might allow the changes indispensable for the modernisation of protected countries - did not destroy the existing social structures and did not hurt the leading mentalities. (Queffélec 1995, 802) [Authors' translation]

\footnotetext{
${ }^{3}$ Religious higher education establishment attached to the Zitouna Mosque.

${ }^{4} \mathrm{Bey}$ is the governor of a district or province in the Ottoman Empire and in this case the city of Tunis.
} 
The Arabic language was relegated backward for the ideological reasons of the colonizer, who emphasizes "sa mission civilisatrice"/its civilizing mission (Pape 2017) and thus justifies the pre-eminence of his language to the detriment of the local languages. Having become a protectorate, Tunisia was subject to a new administration in which the modernization of the education system was one of the most important objectives. Degorge (2002) describes this modernization as follows: a Director of Public Education was appointed to modernize the education system. This system was to foster an understanding of both Arab-Islamic culture and the newly arrived culture, the French culture. To achieve this goal, an education system was established, which was identical in every way to the one having existed in France. The schools in Tunisia were based on the same models as in France and the curriculum was even approved by the French administration. The main language of education was French, and French people taught in Tunisian schools to transmit not only the language but also the French culture (Degorge 2002).

\subsubsection{After the protectorate (1956-present)}

After the independence of 1956, Tunisia started its very own educational system. At first, it began from the scheme left by the French colonial administration. Later on, it gradually made significant transformations in the pursuit of better classroom instructions. A historical perspective on why French was maintained immediately after independence is offered by Mahmoud Messadi, former Tunisian Minister of Education from 1958 to 1968 :

French still plays an important role in some countries of the Third World. We belong to the developing countries, and we need to catch up with the highly industrialized ones. To this end, we possess the French language, which is both a language of work and meanwhile a language of culture. For us, French is less a foreign language to be learnt, rather it is a tool that will allow us to step over the lost centuries that separate us from the developed world. It will help us access the modernity. (Messadi 1967, cited in Belazi 1991, 53). [Authors' translation]

Currently, French is introduced as a subject in the third year of elementary school and continues to be taught as a subject throughout the elementary, middle, and high school stages. Same as standard Arabic, French is taught for eight hours per week when it is first introduced. From the seventh to the ninth grade (known in Tunisia as the 'deuxième cycle de l'enseignement de base), French starts to be more than a simple foreign language; it then becomes a language of instruction. At 
the beginning of the seventh grade, computer science is introduced as a subject and becomes the first to be delivered in French. Nevertheless, math, science, and technology continue to be taught in Arabic.

At the end of the ninth grade, students move up to the high school where they take a common national exam known as the 'premier cycle général de l'enseignement secondaire'. This national exam allows some of the students to move up to what is called in Tunisia 'lycée pilote'. This step is the last common core curriculum Tunisian students have before they are directed to different specialized tracks in high school. At this stage, many subjects, mainly scientific ones, are taught in French, such as math, physics, chemistry, life sciences, biology, and technology. At the same time French language classes, as well as Arabic language classes, have dropped to five hours per week. At the end of the tenth grade, students choose to move up into one of the following streams based on their skills: humanities (lettres), math, economics and business administration, computer science, experimental sciences, and technical sciences.

It is worth mentioning that at this level, Arabic - as the language of instruction is significantly reduced in all non-humanities sections (e.g., math, life sciences). Except for history and geography, and Arabic classes themselves, all other subjects in the science and technology streams are in French. This policy was applied seven years after French was first introduced as a foreign language and four years after it was used as the language of instruction for the first time in computer science classes. In addition to all that, Arabic continues to be taught to non-humanities students for two hours per week. Students in the humanities section continue to have five hours of French class per week, exactly like English, but they do not take any other subject in French, contrary to all other students in the non-humanities streams, for whom French becomes the principal vehicle of instruction.

After the independence obtained in March 1956, the new Tunisian government found itself faced with the need to put into practice the Arabization project, particularly in the education sector. The sixty years that separate us from this date can be divided fairly into three phases.

\subsubsection{From 1956 to the late 1960s.}

At this moment in history, the main goal was to generalize education. In the educational charters, Arabic was designated as the national language and was taught to affirm Tunisian and Arab national identity. French had the status of a vehicle language for science and technology. In this model, the balance of languages is clearly in favour of French. The superiority of French is confirmed as it progresses through the stages of education. It becomes predominant in timetables at the end of primary and secondary school: $70 \%$ of subjects are in French (Jerad 2004). 
At university, French is used almost exclusively in the humanities and all scientific and technical subjects. During this stage, Tunisia is French-speaking. Bourguiba, one of the founders of the "Agence de la Francophonie", claims this francophony by saying: "We will have to continue to adopt French as a vehicle for progress". (H. Bourguiba speech 1979, 301-302)

In his memorable speech on May 11, 1968, in Montreal, President Habib Bourguiba defended, his vision of bilingualism:

On the contrary, we are aware not only of having enriched our national culture, but of having guided it, of having conferred on it a specific mark that nothing will be able to erase. We are also aware of having been able to forge a Tunisian mentality, which is a modern mentality, and of having instilled in the Tunisian people, above all in its elite, the necessary capacity to assimilate the techniques of the world today. (Bourguiba, 1978) [Authors' translation]

Another speech by President Habib Bourguiba, delivered on October 10, 1968, to an audience of teachers in Bizerte, sums up well the situation in what has been considered the "golden age of the French-speaking world" in Tunisia:

Using French does not undermine our sovereignty or our loyalty to the Arabic language, but gives us a wide opening to the modern world. If we have chosen French as the lingua franca, it is to better integrate into the streams of modern civilization and to catch up more quickly ... And it is too little, finally, when we speak of Tunisia, to emphasize its bilingualism: it is rather a matter of biculturalism. Tunisia does not deny anything of its past, of which the Arabic language is the expression. But she also knows well that it is thanks to the mastery of a language such as French that she fully participates in the culture and life of the modern world. (Bourguiba 1978) [Authors' translation]

In any case, the first teaching model was considered selective. The plan to see it implemented on a large scale, the success of bilingual training of the Sadikian elite was not achieved. In 1984, the enrolment rate of the population aged 25 and over, which includes the first generation of students enrolled in this system, was as follows:

\begin{tabular}{|l|r|r|r|r|}
\hline Categories & $\begin{array}{r}\text { Primary school } \\
\text { not completed }\end{array}$ & $\begin{array}{r}\text { Secondary } \\
\text { school }\end{array}$ & Post-secondary & $\begin{array}{c}\text { Declared without } \\
\text { schooling }\end{array}$ \\
\hline Percentage & $18.9 \%$ & $12 \%$ & $2.8 \%$ & 66.3 \\
\hline
\end{tabular}

Figure 1. Enrolment rate of the population aged 25 and over in $1984^{5}$

${ }^{5}$ Unesco. Statistical Yearbook 1999 


\subsubsection{From the 1970 s to 2000}

One can distinguish three stages in the language policy of the Arabization of education in Tunisia. We will briefly describe them to observe the evolution of this process of strengthening French against Arabic.

In the mid-1970s, in the three Maghreb countries, the goal of Arabization was once again the priority. While Algeria opted for a radical Arabization of primary and secondary education and the retention of French in scientific and technical disciplines at the university, Morocco and Tunisia opted for gradual Arabization. In Tunisia, it was Mohamed Mzali, Minister of National Education, who was the promoter of this reform. At the secondary level, the humanities were Arabized: philosophy, history, and geography. But at university, the same disciplines were not entirely Arabized. Scientific and technical subjects remained in French in secondary and higher education.

In 1976, under the nationalist pressure claiming more and more Arabization of human sciences, the teaching of sociology, philosophy, history, and geography were Arabized. Many intellectuals of that time saw this return to the Arabic language as a means of compensating for the identity upheavals caused in particular by French colonization. Surprisingly, French philosophers such as Maurice de Gandillac and Henri Corbin even supported this movement of university Arabization. They argued that, unlike "hard" disciplines, philosophy must be taught in the language of the mother culture, regardless of the universal value of Greek, German, or French concepts.

The end of the 1980s was marked by the rise of Islamist movements in the Maghreb. Arabization is accused of having created this trend, if not contributed to it. In Tunisia, a change of political regime took place against the backdrop of this crisis. In 1989, Mohamed Charfi, former president of the Tunisian League for Human Rights, accepted the post of Minister of National Education and took control, both ideologically and academically, of education, which culminated in the Orientation Act of 1991. It was him and his successors who reformed education as follows:

If primary school and college remain fully Arabized, the teaching of French as a foreign language is re-established from the third year of compulsory schooling and it again becomes the language of sciences at high school, economy and techniques and, simultaneously, becomes the language of openness and of the development of a culture of tolerance; in all these capacities, French is obligatorily formalised with the General Certificate of Education. Other modern languages, in particular English starting with the fifth year of compulsory education, are introduced into the curriculum. The place of French is also tending to be consolidated in higher education, 
especially in the fields from which it had previously been virtually banned (arts and human sciences). (Tullon 2009, 45). [Authors' translation]

At this stage, we recognize the introduction of French as a language of instruction in the 1990s and 2000s, beginning with Grade 3. We, therefore, see a return to the French language at all levels: where it was abandoned in the 1970s and 1980s, it is being reintroduced in the 1990 s and 2000s. However, the place of the French language seems to be threatened by other languages, which are becoming established in society and more specifically in teaching.

The official language policy followed since this change reflects an ambivalent attitude. The objective of the reform was to strengthen the Arab and Islamic culture and identity and thus to reinforce Arabic as a national language through further Arabization. At the same time, however, French is being strengthened by the increase in the number of hours in primary and secondary schools. As Tullon (2009) puts it: in Tunisia, it is indeed English that tends to take an increasingly important place in the lives of Tunisians. As for French, we can well say that after a period of oblivion and abandonment, it has regained its place. But what about the current situation of education in Tunisia?

\subsubsection{From 2000 to the present}

Fifty years after the independence, the Tunisian state has a fundamentally dual education and training system, divided according to the language of instruction. Thus, the beating heart of higher education, i.e. engineering, business studies, and health professions, which have constantly escaped attempts of Arabization and have remained largely French-speaking (Tullon 2009, 46), offers rewarding opportunities for its graduates, particularly in the modern economy; conversely, Arabized higher education (mainly humanities and social sciences, but also legal studies for a part) seems to a significant extent to fuel graduate unemployment.

The year 2000 witnessed the introduction of a competency-based approach in the school curriculum, which needed the revision of textbooks accordingly. In 2002, the Ministry launched a major reform aiming in particular at strengthening the presence of foreign languages, the introduction of information and communication technology support from primary school onwards, etc. The reform is also aimed at improving the quality of education and the quality of teaching. At this level, the return to the French language was supported by the "Program for the Renewal of the Teaching of French in the Tunisian Education System" (PREF/SET) launched in 2003 and completed in 2007, carried out jointly by the Tunisian Ministry of Education and the French Ministry of Foreign Affairs. This program was designed to ensure that teachers whose initial training was deficient (linguistic, 
cultural, scientific, and pedagogical) were brought up to standard, to promote a better francophone environment for students and teachers outside the classroom, and to provide teaching materials that foster the renewal of classroom practices.

Indeed, French enjoys a special status in Tunisia compared to other languages. It is this privileged status that makes the French language taught from the 3 rd year of the 1st cycle of basic education (primary school), around the age of 8 years. After 7 years of learning the language (the last 4 years of primary school and the 3 years of middle school), French becomes, during the 4 years of high school, the language of instruction for scientific, technical, economic, and management subjects. French thus has a significant hourly volume which ranges from 8 -10 hours in primary and middle school to 4 - 5 hours depending on the options in high school, in addition to the hours devoted to subjects taught in French in high school which exceed 10 hours per week. Article 9 of the Law of Orientation of Education and School Education No. 80 of 23 July 2002 states: "L'école est appelée essentiellement à donner aux élèves les moyens : de maîtriser la langue arabe, en sa qualité de langue nationale ; de maîtriser deux langues étrangères au moins." (The school is essentially called upon to give students the means: to master the Arabic language, as a national language; to master at least two foreign languages. (Authors' translation)

Being the first foreign language studied by Tunisian students, "French should contribute to their intellectual, cultural, and scientific training. It will be a complementary means for the student to - communicate with others; - discover other civilizations and cultures and situate oneself in relation to them; - access scientific and technical information" ${ }^{\prime}$. In the preparatory cycle of basic education, the objectives of the teaching of French are articulated around three major orientations: to develop reading skills in students; refining their oral and written expression skills; and to develop their autonomy through the acquisition of appropriate work methods.

In addition to French, Tunisian students study English, which has become increasingly important in recent years. In 2005, French was cut by two hours to reinforce the teaching of English. A measure assumed by the director of training who declared in 2005: "French enjoys the status of a privileged foreign language while the teaching of English is part of a perspective of anti-historical utilitarian plurilingualism that will allow us to go beyond the current bilingualism". Besides, from the second year of secondary school, students have the option of choosing a third language which can be German, Italian, Spanish, Russian, or Chinese, and which is taught for two years at a rate of 3 to 4 hours per week.

\footnotetext{
${ }^{6}$ Programme de français, p. 3.
} 
Throughout the reforms and especially the Arabization policy, French, the main language of teaching and administration during the French colonization, was shrunk and even tumbled in education in Tunisia. The number of hours and subjects studied in French has continued to decline since the 1980s. It is worth stating that the teaching of French has not suffered from these reforms in the French schools applying French curricula, established in Tunisia.

Since 1991, we have experienced a gradual return to bilingualism in education extended to multilingualism with the reforms promote after the 2011 revolutionary movements in Tunisia when the linguistic debate was put again at the core of political confrontations. In political debates, especially within the parliament, some deputies were strongly criticized because of their use of French. They were even a subject of mocking among the social media users because of their linguistic mistakes.

Tunisian post-revolutionary policymakers believed in the fact that in an era of globalization, bilingualism, or even plurilingualism, is an indispensable condition for success in education, work, and economic, political, and social exchanges. Also, as Hortobágyi (2009) puts it: “.... all over the world, educators have to develop radical pedagogical structures which provide students with the opportunity to exploit their own cultural identities and linguistic realities as a basis of oral and written communication". The United Nations Educational, Scientific and Cultural Organization (UNESCO) explains that speaking three languages "should be the normal range of language knowledge in the 21st century". Seeing countries investing massively to promote the plurilingualism of their population is only a normal consequence of such a statement. One need only consult numerous documents of the European Commission to see the importance given to this issue.

The eagerness of the Tunisian Ministry of Education to deal with this urgent and thorny issue is perfectly understandable as it comes in response to growing social pressure. Starting from 2019, students began to study the French language from the second year of primary school and English from the fourth year of the same cycle.

In the Tunisian case, Berber is perhaps the forgotten language in these elite debates. In its nineteenth periodic report (2006), the Tunisian government states: "As far as the Berbers of Tunisia are concerned, it can be stated that they are particularly well integrated into the Tunisian society and that they have no claims". However, the claims of the Amazighs of Tunisia were summed up in the right to affirm their language and culture alongside the Arabic language and culture. Moreover, the first article of the Tunisian constitution stipulating that: "Tunisia is a free, independent and sovereign state; its religion is Islam, its language is Arabic 
and its regime is republic" shows that there is no political will to support the expression of Amazigh culture, identity, and language in Tunisia.

\subsection{Status and role of English in Tunisia}

English started to be taught in Tunisian schools shortly after Tunisia's independence in 1956. Battenburg (1997) stated that the "Institut Bourguiba des Langues Vivantes" (IBLV) established in 1957 was the first institution promoting English in Tunisia. In education, English was taught from the second to the sixth year of secondary school for all sections. From 2000 until 2007, this phase was characterized primarily by the lowering of the age of learning English in primary schools in 2005 as it became taught from the 6th year. English first started in primary schools as a club. As the club developed into a compulsory subject, the Ministry of Education and Training was debriefing schools and teachers about the changes happening as well as the objectives, the approach, the manuals to be used, the expected teaching conditions and the assessment procedures. Such an act was certainly taken as a result of growing awareness about the importance of teaching English at an early age to promote mastery of it. The English language continues to be taught in universities as well, irrespective of the field of the study. Nowadays it is an obligatory subject in school that everyone had to take.

With the emergence of globalization, the function of English has markedly changed becoming a tool to achieve global outreach. Nowadays, we can admit that English is present at all levels in the Tunisian square. In this context, Aouina (2013 39) dissects, "English has...jumped over the school fences to start invading streets and people's daily life". Many scholars such as Boukadi and Troudi $(2017,264)$ admit that Tunisians nowadays have different linguistic needs from before. Further claims encourage the perception that this has particularly been reinforced by the 2011 revolution (the Arab Spring) where the Tunisian youth found it more spirited to share their thoughts with the world writing in English.

According to some studies, Tunisian teenagers seem to use English more than the older generation in their daily life. For instance, English has started to be a language switched to by Tunisians apart from French. This may be due to mass media and to computer-mediated communication that has promulgated several English terms. Some linguists think that this may partly be due to the extensive use of English as a lingua franca, especially with tourists who visit Tunisia by millions every year. 


\section{Language policy vs. language practices: paradox and confusion}

In the process of conscious multicultural education, it is important to be able to deconstruct a given experience or situation and decompose it into discreet elements that allow greater insight and reveal presumed sources of prejudice (Hortobágyi 2009). A quick review of the state laws on the official use of languages and language practices in social life reveals that the two languages that are the subject of the laws, Arabic and French, are neither the mother tongue of Tunisians nor the language in which exchanges in the daily life of the society take place. The Arabic spoken in Tunisia is the only living language in the everyday life of almost the entire population. In certain situations of communication, French can be used in alternation with spoken Arabic, but in these situations of mixed codes, from the speaker's point of view, the mixture of languages is seen as a single language. The language of the Tunisian theatre reflects this linguistic crossbreeding by demonstrating that the verbal repertoire of Tunisians is necessarily open to all languages present in the linguistic horizon. In the landscape and the daily environment of the Tunisian, French, officially presented as a foreign language, is everywhere present especially in written form. The landscape of the city: street names, signs of the highway code, road signs, signs, advertising, shows that French cohabits with Arabic and sometimes exceeds it in signs. In an ethnographic study of linguistic landscape in Tunisia, Ben Said $(2010,4)$ stated that: "Although not officially recognized in Tunisian legislation, French in Tunisia was shown to have a substantial impact on the linguistic landscape, especially on private signs".

As individuals communicate with each other, they mark their identity through language. Identity is often understood as who a person is, or the characteristics of an individual or community that make them distinct from others. It is the way one defines his or her relationship with the globe, according to Norton (2013), and how that relationship is built through space and time. Social media platforms that provide connection of people from all over the globe have provided more opportunities for multilingual encounters and translingual practices, which has revitalized languages and led to assertion of new identities (Darvin 2016).

Browsing on Facebook, we choose to check the different forms of languages Tunisians use on this online platform. Facebook offers its users different writing spaces where they can express themselves, share their thoughts, and even instantly share moments they live. Four writing spaces are thus available to scriptwriters: Instant Discussions, Comments, Statutes, and Facebook stories. As comments and sometimes Facebook stories are easier to find publicly shared, we have decided to observe these two writing spaces and comment on the linguistic practices found there. For this reason, we thought of the famous group "Ya Gdim !! 
(80s - 90s)", which is an assembly of Tunisians from different generations gathering in this group to remember and share memories from old times, which they believe they have in common. The title of the group itself is an Arabic expression - literally "old" meaning "outdated" - written in Latin script. The word is sometimes written in this way "ديم" in the comments. It is a word expressed in Tunisian and written in Arabic using a single letter of the Latin alphabet. This recourse is used to express a phoneme ([g]) referring to a regional variant of Tunisian that does not exist in the standard Arabic alphabet.

The following excerpts are taken from Statutes published between 2019 and 2020. As we will see, several types of spellings are used by Tunisian Facebook users to express themselves in different languages: notably standard Arabic (MSA), French, and Tunisian. According to our observations, it seems possible to characterize the writing of the selected Statutes according to two aspects: one relating to the language used, the other to the graph used.

(1) Examples of the use of Latin script

a. expression in Tunisian:

nhebik barcha. (B.K)

'I love you so much'

b. expression in Tunisian and French

merci beaucoup, win Ikitha, hhhhhh, super, super sympa (M.B.)

'Many thanks, where did you find it, great, super lovely'

c. expression in French:

J'adore à Monastir aussi on avait les mêmes troupes» (L.N.)

'I like, in Monastir, we had the same groups'

d. expression in Standard Arabic

Orsileha ila rouh Abi [...] 27 octobre thikra wafatihi. (A.B)

'I dedicate it to my father's soul [...] 27 October anniversary of his death'

(2) Examples of the use of numbers with Latin spelling

a. expression in Tunisian and French

Je l'adore kol chay ya3rfou [...]. (S.M.)

'I love him, he knows everything [...]'

b. expression in Tunisian

hedhy Im3alma. (S.J.)

'This is the boss' 
(3) Examples of the Use of Arabic writing

a. expression in Tunisian

اي متو اقدي م ح ق حق (R.J)

'Yes! now this is the real outdated'

b.expression in French:

(I.N.) 'probleme' 'I like'

(I.N.) 'problème' 'problem'

c. expression in Standard Arabic and French:

(B.M.)

'Bonjour (good morning) to the best outdated'

d.expression in Tunisian and French

هof.H.)

'Hhhhhh This is a special mathematics'

e. expression in Standard Arabic

(F.C.)

'One of the best memories'

f. expression in Tunisian and Standard Arabic

الزمن الجمبل و الخبر و البركة و الدخاخ النظيفة و التربية (F.J.)

'The beautiful and benevolent time, the blessings, the clean minds, and the education'

(4) Example of the use of two spellings in Arabic and Latin for expression in Tunisian and French

a. أعبد الحليب حافظinoubliable (N.S.)

'Abd Alhalim Hafidh is unforgettable'

b. قداش كنت نحبهاcette publicité (H.D.)

'How much I used to love this advertisement'

These examples are not exhaustive. Other languages also circulate such as Egyptian, English, Spanish, or Italian and many other possibilities have also been noted. It is also worth noting that several features characterize these writings. Facebook users show high ability in mixing languages and scripts (see examples in Figure 1): French, standard Arabic, Tunisian, two by two, sometimes all three. 


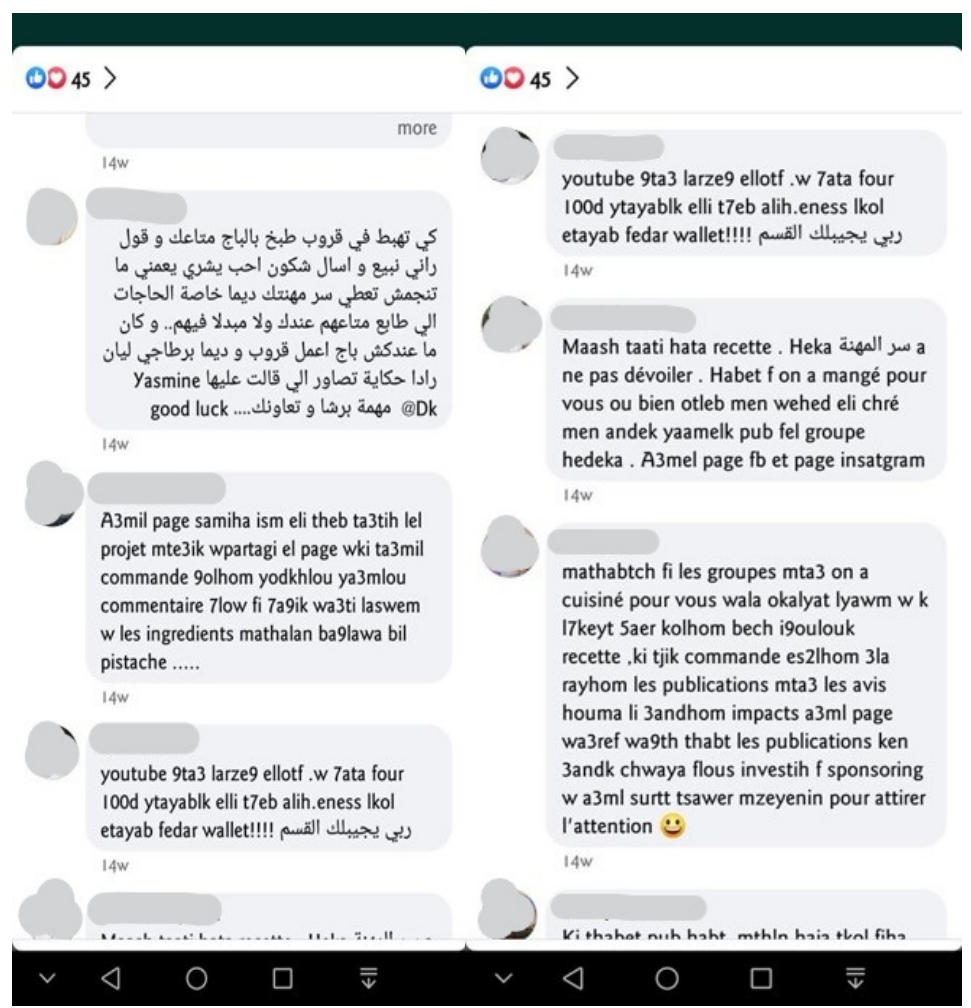

Figure 2. Screenshots taken from Facebook, retrieved on 5th of September 2020

According to Gervasio and Karuri (2019), when people occupy online platforms, they reconstruct language in ways that match the constraints and affordances of different digital spaces. Users of social media take photos and upload them or share status updates in real time and space, rendering the process a naturalized practice. This being the case, observing Facebook Stories, similar features were found. Taking the example of G.R. who, in a time slot of two hours, posted seven stories (see figure 3). From the seven stories, three were in English, one in Tunisian Arabic, one in Modern Standard Arabic, one in Egyptian Arabic, and one in French and Tunisian Arabic. These mixtures of languages and more are usually found in Tunisians' Facebook or Instagram Stories. The variation in language usage and graphics is also strongly present. When browsing through many stories, we note that, apart from other languages, variants of the Arabic language are also present. People tend to self-express in the social media while spontaneously displaying their linguistic identities in real time and space. 

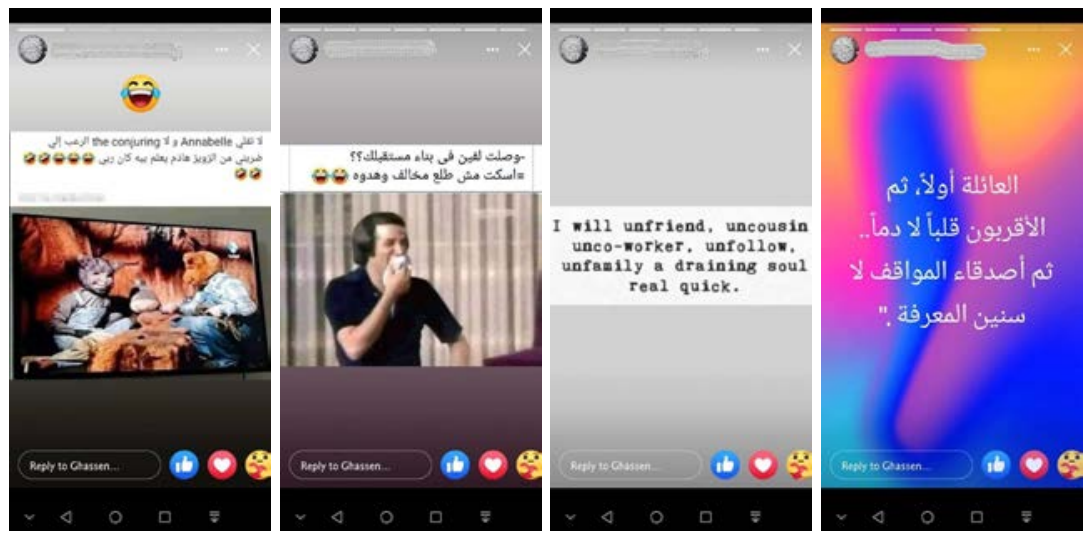

Figure 3. Screenshots of Facebook Stories taken from G.R.'s profile

In addition, these examples show the possibility of knowingly getting rid of the systematization of the use of the Latin alphabet for writing French, which can perfectly serve as a writing medium for standard Arabic or Tunisian.

Standard Arabic and French are, today, the two main written languages in the country. Standard Arabic is officially recognized according to the first and then the second Tunisian Constitution (1959 and 2014). The latter insists even more firmly than the former on the importance of the status of the standard Arabic language by linking it to identity issues. Indeed, Article 1, reaffirming that Standard Arabic is the language of the country, is reinforced by Article 39, which expresses the state's commitment to 'rooting Standard Arabic' with 'Arab-Muslim identity'. This ideologization of the standard Arabic language is not new (the Arabization policy in the late 1970s).

The State, by proclaiming that its language is Arabic, denies the reality of linguistic customs and facts. By giving French an important place in the landscape and semiology of the city, it accentuates its contradiction by trying to deny a language that is part of the linguistic landscape of the city and the lives of Tunisians. Whether he speaks it or not, French is part of the linguistic horizon of the Tunisian. The foreign visitor will therefore notice that French as a foreign language officially occupies the same status as Arabic. All inscriptions of state institutions - ministries, public buildings, signs, road signs, train stations, and airports - are given to the public in both languages. For those who do not practice classical Arabic or French, this can be felt as a form of symbolic violence and exclusion by languages. 


\section{Concluding remarks}

Tunisia, similarly to other northern African countries (e.g. Algeria and Morocco), is a francophone nation par excellence, where the French language enjoys a very privileged status. As Marley and Aitsiselmi $(2008,186)$ put it, "[The status of French] is far from that of a mere 'foreign language', which is the only official role it retains". This fact might presumably explain why Arabic and French are, in terms of Bahloul (2001, see the link in References), "in a state of flux which is considerably influencing the development of English [which has been for decades] on the periphery of the language scene [in Tunisia]".

One remark concerns the role of French as the first foreign language in education: access to universal knowledge, scientific and technical progress; here again, we find ourselves in the implicit reproduction of the colonial ideology that justified the introduction of French to bring about progress. In the current context, we find ourselves implicitly defending French as a universal language and resisting English, which is currently the language of access to universal knowledge. This confirms L. J. Calvet's remark (Les politiques linguistiques 1996, 120):

But the most striking effect of history on linguistic situations lies undoubtedly in the fact that the Maghreb countries, on their own territories, are ensuring a leading/important status to one of the most widely spoken languages in the world, while France is working on the status of its language in the world. ${ }^{7}$ [Authors' translation]

Furthermore, at university, all scientific and technical disciplines are taught in French. Social sciences and humanities also include a proportion of subjects taught in French. Hence Stevens' remark: "to be educated in Tunisia is to be a French speaker" (1983, 108).

Consequently, attempts to promote English in education since the independence was most welcomed by the Tunisian policymakers. In this light, things have been dramatically altered especially after the Arabic Spring. Thirty years ago, English had been introduced as a FL in the first grade of the elementary school and ever since the implementation of English gradually shows the raise of awareness of its importance in all domains of life. For instance, since 1994, English

\footnotetext{
7 This is not a very explicit formulation of a situation of francophony, which can be read in the conclusion to the chapter devoted to the Maghreb in his book Les politiques linguistiques (Paris, PUF 1996, 120). However, it is clear from the assessment of the relationship between Arabic and French that the author seems to mean that the Maghreb illustrates a situation of resistance of the French language in a context where France is trying to defend its language in the world.
} 
has been taught in primary schools; nowadays it has become a compulsory subject for all students and is taught across all levels in school.

The history of educational reforms shows that the teaching of foreign languages is one of the major axes of the Tunisian educational policy. As French is the first foreign language studied by Tunisian students, its mastery by young people represents both an option and a challenge.

The study of educational reforms in Tunisia provides evidence of the linguistic policy of the country as well as of the linguistic practices that are not in line with the pronounced official policies. Besides, linguistic practices encountered in mediated communication platforms provide evidence not only for existing identities but also for model and project emerging identities.

A close look at the linguistic practices of Tunisians in the social media has uncovered several myths about the discrepancy between the official language policy advocating MSA as the unique language of the state and the linguistic practices which are in stark contrast with the institutional advocacies of monolingualism. More specifically, the linguistic practices provide a more genuine and germane picture of how language diversity encountered in the social media contradicts the dominant and hegemonic national discourses promoting monolingualism.

\section{References}

Aitsiselmi, Farid and Marley Dawn. 2008. "The role and status of the French language in North Africa." Studies in French Applied Linguistics 21(11): 185-222.

Alexandre, Pierre. 1967. Langues et langage en Afrique noire. Payot.

Aouina, Hichem. 2013. "Globalisation and language policy in Tunisia: Shifts in domains of use and linguistic attitudes." PhD diss., University of the West of England.

Bahloul, Mongi. 2001. "English in Carthage; or, the 'tenth crusade'." Retrieved from http://www.postcolonialweb.org/poldiscourse/casablanca/bahloul2.html.

Battenburg, John. 1997. "English versus French: language rivalry in Tunisia”. World Englishes 16(2): 281-290.

Belazi, Hedi Mohammed. 1991. "Multilingualism in Tunisia and French/Arabic codeswitching among educated Tunisian bilinguals." Unpublished Ph.D. dissertation. Cornell University, Ithaca, NY.

Ben Said, Slim. 2010. "Urban street signs in the linguistic landscape of Tunisia: Tensions in policy, representation, and attitudes." Retrieved from https://etda.libraries.psu.edu/catalog/10966 
Boukadi, Samira and Salah Troudi. 2017. "English Education Policy in Tunisia, Issues of Language Policy in Post-revolution Tunisia." In English Language Education Policy in the Middle East and North Africa, 257-277. Springer, Cham.

Bounfour, Abdellah. 1994. Le nœud de la langue: langue, littérature et société au Maghreb. FeniXX.

Bourguiba, Habib. 1978. "Discours d'Athènes 1965 ». Discours, volume XIII, 1964-65. Publications du Secrétariat d'État à l'Information : Tunis.

Bourguiba, Habib. 1979. Discours. Publications du Centre de documentation Nationale, Tunis, t. XVII, p. 301-302.

Calvet, Louis-Jean. 1996. Les Politiques linguistiques. (Que Sais-Je?) Paris: Presses Universitaires de France, 128 pp. 2130474896.

Coupland, Nikolas (ed.). 2016. Sociolinguistics: theoretical debates. Cambridge University Press.

Daoud, Mohamed. 2001. "The language situation in Tunisia." Current Issues in Language Planning 2(1): 1-52.

Daoud, Mohamed. 2011. "The sociolinguistic situation in Tunisia: language rivalry or accommodation?" International journal of the sociology of language 211: 9-33.

Darvin, Ron. 2016. "Language and identity in the digital age." The Routledge handbook of language and identity 523-540.

DeGorge, Barbara. 2002. "The modernization of education: A case study of Tunisia and Morocco." The European Legacy 7(5): 579-596.

Gervasio, Miriti and Mary Karuri. 2019. "Marking Identity through Language in Social Media Discourse by Chuka University Students". International Journal on Studies in English Language and Literature (IJSELL) Volume 7, Issue 8, August 2019, PP 43-52 ISSN 2347-3126 (Print) \& ISSN 2347-3134 (Online) http://dx.doi.org/10.20431/2347-3134.0708005.

Grandguillaume, Gilbert. 1983. Arabisation et politique linguistique au Maghreb. Vol. 19. Maisonneuve \& Larose.

Hortobágyi, lildiko. 2009. 'Individual Voices in Contemporary Communication', in 7th Conference on British and American Studies. Brasov: Transylvania University Press, 171-178.

Hortobagyi, Ildiko. 2015. "Multiculturalism or cosmopolitan identity? The UK riots revisited." TOPOS: Journal of Space and Humanities. Veszprém 4(1): 53-65.

Hortobagyi, Ildiko. 2017a. "The linguistic rhythms of urban spaces: New approaches to everyday multilingualism." TOPOS: Journal of Space and Humanities. Veszprém 6/ (2). pp. 97-108. 
Hortobagyi, Ildiko. 2017b. "Renegotiating Meaning in Multimodal Media Contexts. Synergy." Journal of the Department of Modern Languages and Business Communication. University of Bucharest, Romania, Vol. 13/No. 1/2017: 145-161.

Jerad, Nabila. 2004. "La politique linguistique dans la Tunisie postcoloniale.» Dakhlia, J. (sous la direction). Trames de langues. Usages et métissages linguistiques dans I'histoire du Maghreb. Paris: Maisonneuve \& Larose.

Lacheraf, Mostefa. 1965. L'Algérie: nation et société. FeniXX.

Norton, Bonny. 2013. Identity and language learning: Extending the conversation. Multilingual matters.

Pape, Maryam. 2017. "Brain drain à la tunisienne»: quels effets ou contre-effets didactiques et sociolinguistiques d"une politique d"arabisation? Master's thesis, Institut de Recherche et de Formation en Français Langue Etrangère, Université de Nantes.

Queffélec, Ambroise. 1995. "Le français en Afrique du Nord: 1914-1945.» In. Histoire de la langue française 1914-1945, ed. by Antoine, Gérald, and Robert Martin, Vol. 15, 791-822. CNRS.

Riguet, Maurice. 1984. Attitudes et représentations liées à l'emploi du bilinguisme. Vol. 10. Publications de la Sorbonne.

Smari, Ibtissem and Judit Navracsics. 2019. Multilingualism and its impact on identity: Tunisian case study. Alkalmazott Nyelvtudomány, XIX. évfolyam, 2019/1. Szám doi:http://dx.doi.org/10.18460/ANY. 2019.1.005

Sraîeb, Noureddine. 2000. "Place et fonctions de la langue française en Tunisie.»Documents pour l'histoire du français langue étrangère ou seconde 25 : 211-219.

Stevens, Paul B. 1983. "Ambivalence, modernisation and language attitudes: French and Arabic in Tunisia." Journal of Multilingual \& Multicultural Development 4, no. 2-3: 101-114.

Tullon, Hubert. 2009. "Arabe et Français dans les systèmes éducatifs Tunisien et Marocain au tournant du XXIe siècle.» Synergies Tunisie 1: 39-51.

World Bank. 2008. "The road not traveled: Education reform in the Middle East and North Africa." MENA Development Report. Washington, DC: World Bank. (c) World Bank. https://openknowledge.worldbank.org/handle/10986/6303 License: CC BY 3.0 IGO. 


\section{Official documents}

Constitution de la République tunisienne [Tunisia], January 2014, available at: https://www.refworld.org/docid/54c25ac94.html [accessed 18 June 2020]

Les programmes de français cycle préparatoire de l'enseignement de base, 2006, Tunis, Ministry of Education and Training.

Les programmes officiels de français, 2005. Tunis, Ministry of Education and Training.

The Orientation Law on Education and School Education No. 80 of July 23, 2002, Tunisia.

The Constitution of Tunisia, 1959. World Intellectual Property Organization. Retrieved 18 June 2020.

Law on the Orientation of Education and Teaching No. 91-65 of July 29, 1991, Tunisia. 